\title{
Thymic Tumor Pathologic Regional Lymph Nodes TNM Finding v8
}

National Cancer Institute

\section{Source}

National Cancer Institute. Thymic Tumor Pathologic Regional Lymph Nodes TNM

Finding v8. NCI Thesaurus. Code C136314.

A pathologic finding about one or more characteristics of a thymic tumor, following the rules of the TNM AJCC V8 classification system as they pertain to staging of regional lymph nodes. 